\title{
The Experiences of Students in Using Online Learning Platform During the Covid-19 Lockdown in Indonesia
}

\author{
Leny Novita ${ }^{1}$, Yu-Chuan Yang $^{2}$, Titin Rahmiatin Rahim ${ }^{3}$ \\ 1,2,3 National Dong Hwa University, Taiwan
}

\begin{abstract}
This study explores students' experience using online learning during the COVID 19 in Indonesia. The study employed qualitative data from an online questionnaire and interview through WhatsApp voice call. The experience of the five students during their learning online was examined, analyzed, and described. The findings showed that the five students revealed cognitive and affective responses. There were general themes presented in their responses, including (a) Prefer to study in a real classroom, (b) Creative teachers provide many learning strategies and are consistent, (c) Feeling bored and tired while studying online, (d) Family and technological support.
\end{abstract}

\section{CONTACT}

ycyang@gms.ndhu.edu.tw

\section{KEYWORDS}

Online learning, Students'

responses

\section{INTRODUCTION}

The world has been hit by a health crisis that is coronavirus or COVID-19, including in Indonesia since 2020. All aspects of life have changed, and everyday life has also become abnormal. Ordinary life does not become routine, especially in education. In his circular letter, the Minister of Education and Culture of Indonesia (2020) stated that the learning process is currently being carried out at home. Online learning was a result of anticipating the spread of the COVID-19 virus. The home learning process aims to provide a meaningful learning experience for students without burdening them with all the curriculum demands [1].

It is the first time for Indonesian students to learn from home online. The researchers are very interested in studying how the experience gained by students in senior high school during their learning from home, during the pandemic about students' experience in using the online learning platform, and during the COVID-19 lockdown in Indonesia.

The research about the personal and student experience in online learning addressed the amount of information, such as discussion forums, student interactions with others, and other learning support (Gilbert et al., 2007) [2]. The constraints of written communication and lack of human interaction caused difficulties in adjusting and coping with the online learning environment (Symeonides, \& Childs, 2015) [3]. However, research on students' experiences during the coronavirus pandemic is still very little research, especially in Indonesia. So, the authors of this study felt it very necessary to know how their learning experience at this time.

\section{Purpose of the study}

This study aimed to know the experience of natural science senior high school students in using online learning platforms during the COVID-19 lockdown in Indonesia.

The research questions guided the study:

1. What is the experience of natural science senior high school students in using an online learning platform during the COVID-19 lockdown in Indonesia?

\section{METHODS}

This study was qualitative research that aimed to know how the student learning experience during the coronavirus pandemic in Indonesia. Data collection was from open questionnaires and interviews. The interview used was semi-structured. The interview began by asking the respondent's identity and asking about the respondent's health condition until the respondent felt comfortable, then asked questions planned. The researcher asked some supporting questions to collect more essential things from the respondent's responses. All questions in the interview and open questionnaires were relating to students' experiences, obstacles, and difficulties during online learning because of a pandemic. All the interviews were recorded, carefully transcribed, and subsequently checked for accuracy against the original recordings. The researchers reviewed the responses for (a) Prefer to study in a real classroom, (b) Creative teachers provide many learning strategies and are consistent, (c) Feeling bored and tired while studying online, (d) Family and technological support. The researchers analyzed student responses in online learning experiences. Students prefer to study in a real classroom and have creative teachers who provide many learning strategies and are consistent in online learning. Also, students feel bored and tired while studying 
online; and family and technology supports are essential. The initial themes were refined by overlapping ones, capturing the main thrust of each theme's meaning, and re-examining them through member checking (Guba \& Lincoln, 1994) [4].

\section{Participants}

The students who filled in the open questionnaires online were 149 senior high school students, including $60 \%$ female and $40 \%$ male. All the students used an online learning platform and came from different schools, classes, and majors during the academic calendar 2019-2020 years. The data are shown in Table 1 below.

Table 1. Descriptive data of the 149 students

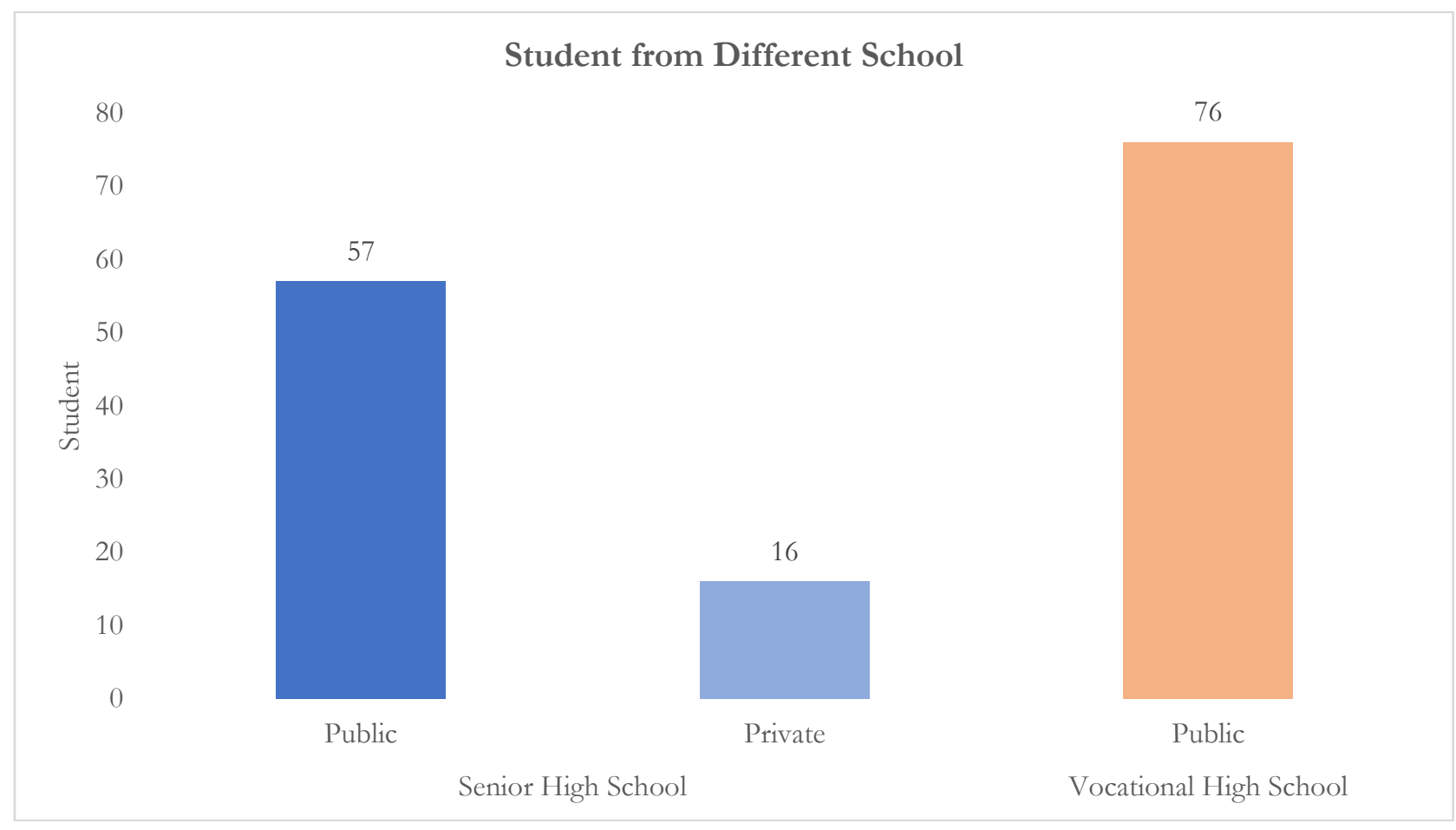




\section{Student Gender}

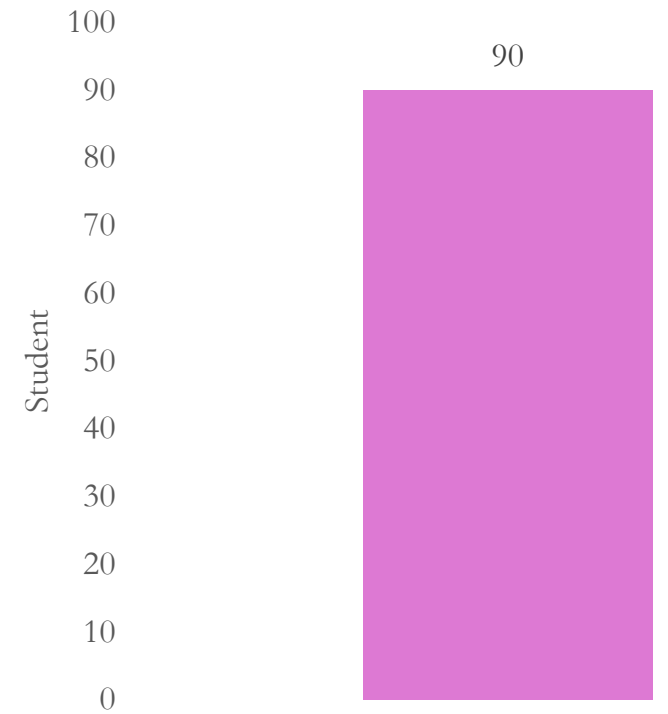

Female
59

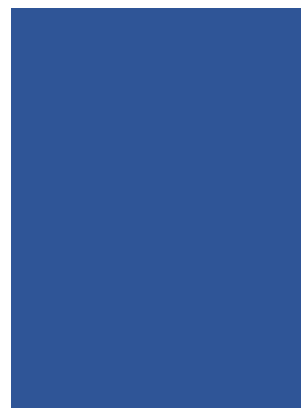

Male

Gender

80

60

苞 40

30

20

10

0

\section{Student Major}

75

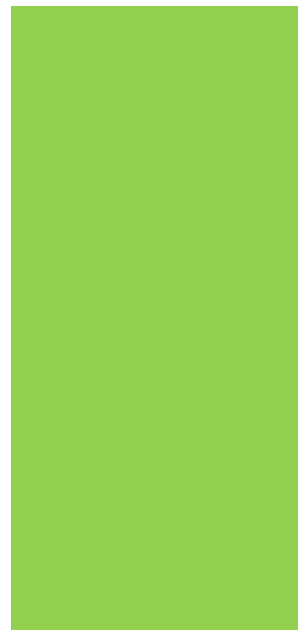

Natural science
74

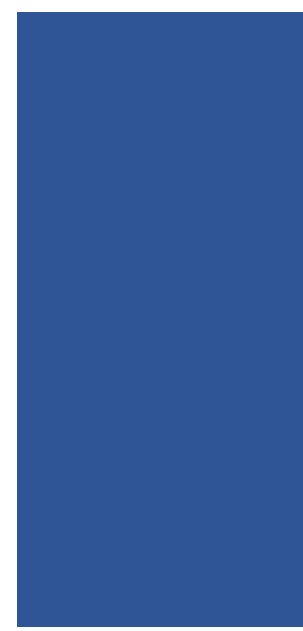

Social science

Major

Purposive homogenous sampling to obtain a closely defined group from whom the experiential research question is significant. After looking at the diverse and incomplete answers to the open questionnaire, it wasn't easy to analyze the rough responses. Then researchers narrowed it down to a high school and selected 2 females and 3 male students aged between 16 and 17 years to collect personal information to dig more into the student responses. These interviewees gave honest answers and were from the same grade, class, and public senior high school in Indonesia. The teacher gave the researchers admission to interview the students. Then the participants were interviewed using WhatsApp application voice call to follow up the answers. Each interview needed approximately 30 to 45 minutes to complete. Participants were named using the first letter of their names. The participants' background for the interview was as in Table 2. 
Table 2. Participants background for the interview

\begin{tabular}{cllccccc}
\hline Number & Name & Sex & $\begin{array}{c}\text { Age } \\
\text { (Years) }\end{array}$ & School & Department & Class & $\begin{array}{c}\text { Rank in } \\
\text { the Class }\end{array}$ \\
\hline 1 & MFF & Male & 16 & Public Senior High School & Natural Science & 11 & 6 \\
2 & DC & Male & 17 & Public Senior High School & Natural Science & 11 & 18 \\
3 & FA & Male & 16 & Public Senior High School & Natural Science & 11 & 8 \\
4 & RKB & Female & 17 & Public Senior High School & Natural Science & 11 & 1 \\
5 & DPT & Female & 16 & Public Senior High School & Natural Science & 11 & 2 \\
\hline
\end{tabular}

This study used two sources to collect data, including open questionnaires and interviews. The interview consisted of questions:

1. Do you like studying in class? Why?

2. Do you like studying from home? Why?

3. What social media/apps did your teacher use while you were studying from home?

4. The learning media used by your (compulsory) math teacher while you are studying from home?

5. What obstacles did you face while studying from home?

6. What lessons did you like studying from home? Why?

7. What do you think is the most creative subject teacher during online learning? Why did you choose that teacher?

8. Did you get good math scores while studying at home? Can you write down how much you scored?

9. How many compulsory math assignments did your teacher give you while studying from home?

10. In your opinion, what are the drawbacks of learning from home?

11. In your opinion, what are the advantages of studying from home?

12. What do you think is needed while studying from home? give your explanation

13. What do you think is the difference between teaching compulsory math teachers in the first class and teaching online (home)?

14. What do you suggest (for students, teachers, parents, and school authorities) to make learning from home better in the future?

15. Imagine if you were a minister of education, principal, or teacher in your country; what would you do to keep your students learning from home during this lockdown?

16. Write down words/sentences that represent how you feel while studying from home?

Table 3. Questions to interview

\begin{tabular}{cl}
\hline Number & Questions \\
\hline 1 & Do you like studying in class? Why? \\
3 & Do you like studying from home? Why? \\
4 & The learning media used by your (compulsory) math teacher while you are studying from home? \\
5 & What obstacles did you face while studying from home? \\
6 & What lessons did you like studying from home? Why? \\
7 & What do you think is the most creative subject teacher during online learning? Why did you choose that teacher? \\
8 & Did you get good math scores while studying at home? Can you write down how much you scored? \\
9 & How many compulsory math assignments did your teacher give you while studying from home? \\
10 & In your opinion, what are the drawbacks of learning from home? \\
11 & 17. In your opinion, what are the advantages of studying from home?
\end{tabular}


12 What do you think is needed while studying from home? give your explanation

13 What do you think is the difference between teaching compulsory math teachers in the first class and teaching online (home)?

14 What do you suggest (for students, teachers, parents, and school authorities) to make learning from home better in the future?

15 Imagine if you were a minister of education, principal, or teacher in your country; what would you do to keep your students learning from home during this lockdown?

16 Write down words/sentences that represent how you feel while studying from home?

\section{RESULTS AND DISCUSSIONS}

Based on research conducted open questionnaires and checked the student responses, the researcher needed to investigate and dig more students' experiences and collect more data about studying online from home by interviewing the students. Researchers extended, rearranged, and redesigned the questions again from 14 questions to 16 questions. The researchers used semi-structured interview questions and decided the order of question number by following up the answers from the open questionnaires; then did interviews to see the students' honest responses and conditions. The obtained results were shown in Table 3.

Table 4. Theme and sub-themes related to answers to interview questions

\begin{tabular}{|c|c|c|c|}
\hline Num & Theme & Sub-theme & \multirow{7}{*}{$\begin{array}{l}\text { Questions } \\
\text { Do you like studying in class? Why? } \\
\text { Do you like studying from home? Why? } \\
\text { What social media/apps did your teacher use } \\
\text { while you were studying from home? } \\
\text { In your opinion, what are the drawbacks of } \\
\text { learning from home? } \\
\text { In your opinion, what are the advantages of } \\
\text { studying from home? } \\
\text { What do you think is needed while studying } \\
\text { from home? give your explanation }\end{array}$} \\
\hline 1 & \multirow{6}{*}{$\begin{array}{l}\text { Prefer to study in a real } \\
\text { classroom }\end{array}$} & $\begin{array}{l}\text { Need interaction with their } \\
\text { classmates and teacher }\end{array}$ & \\
\hline 2 & & Jearning resources & \\
\hline 3 & & & \\
\hline 10 & & Barrier in online learning & \\
\hline 11 & & $\begin{array}{l}\text { Benefit from learning from } \\
\text { home (online) }\end{array}$ & \\
\hline 12 & & $\begin{array}{l}\text { Barrier when studying from } \\
\text { home }\end{array}$ & \\
\hline 13 & \multirow{5}{*}{$\begin{array}{l}\text { Creative teachers provide } \\
\text { many learning strategies } \\
\text { and are consistent }\end{array}$} & $\begin{array}{l}\text { Teacher used learning } \\
\text { strategies by using video and } \\
\text { journal }\end{array}$ & $\begin{array}{l}\text { The learning media used by your (compulsory) } \\
\text { math teacher while you are studying from } \\
\text { home? } \\
\text { What do you think is the difference between } \\
\text { teaching compulsory math teachers in the first } \\
\text { class and teaching online (home)? }\end{array}$ \\
\hline 6 & & $\begin{array}{l}\text { Prefer lessons outside their } \\
\text { majors }\end{array}$ & \multirow{4}{*}{$\begin{array}{l}\text { What lessons did you like studying from } \\
\text { home? Why? } \\
\text { What do you think is the most creative subject } \\
\text { teacher during online learning? Why did you } \\
\text { choose that teacher? } \\
\text { Did you get good math scores while studying } \\
\text { at home? Can you write down how much you } \\
\text { scored? } \\
\text { How many compulsory math assignments did } \\
\text { your teacher give you while studying from } \\
\text { home? }\end{array}$} \\
\hline 7 & & $\begin{array}{l}\text { Activities given by the } \\
\text { teacher }\end{array}$ & \\
\hline 8 & & Feeling about their scores & \\
\hline 9 & & $\begin{array}{l}\text { Consistent teacher in } \\
\text { learning assignment }\end{array}$ & \\
\hline 15 & $\begin{array}{l}\text { Feeling bored and } \\
\text { tired while studying } \\
\text { online }\end{array}$ & Hopes and felling & $\begin{array}{l}\text { Imagine if you were a minister of education, } \\
\text { principal, or teacher in your country; what } \\
\text { would you do to keep your students learning } \\
\text { from home during this lockdown? } \\
\text { Write down words/sentences that represent } \\
\text { how you feel while studying from home? }\end{array}$ \\
\hline
\end{tabular}




\begin{tabular}{ccll}
\hline \multirow{2}{*}{14} & Family & $\begin{array}{l}\text { What do you suggest (for students, teachers, } \\
\text { parents, and school authorities) to make } \\
\text { Family and technological } \\
\text { support }\end{array}$ & $\begin{array}{l}\text { learning from home better in the future? } \\
\text { What obstacles did you face while studying } \\
\text { from home? }\end{array}$ \\
\cline { 2 - 3 } & & Internet & \\
\hline
\end{tabular}

Table 4. Theme and sub-themes related to answers to interview questions

\begin{tabular}{|c|c|c|c|}
\hline Theme & Sub-theme & Item & Questions \\
\hline \multirow{6}{*}{$\begin{array}{l}\text { Prefer to study in a real } \\
\text { classroom }\end{array}$} & $\begin{array}{l}\text { Need interaction with } \\
\text { their classmates and } \\
\text { teacher }\end{array}$ & 1 & Do you like studying in class? Why? \\
\hline & & 2 & Do you like studying from home? Why? \\
\hline & Learning resources & 3 & What social media/apps did your teacher use while you \\
\hline & $\begin{array}{l}\text { Barrier in online } \\
\text { learning }\end{array}$ & 10 & $\begin{array}{l}\text { In your opinion, what are the drawbacks of learning from } \\
\text { home? }\end{array}$ \\
\hline & $\begin{array}{l}\text { Benefit from learning } \\
\text { from home (online) }\end{array}$ & 11 & $\begin{array}{l}\text { In your opinion, what are the advantages of studying from } \\
\text { home? }\end{array}$ \\
\hline & $\begin{array}{l}\text { Barrier when studying } \\
\text { from home }\end{array}$ & 12 & $\begin{array}{l}\text { What do you think is needed while studying from home? } \\
\text { give your explanation }\end{array}$ \\
\hline \multirow{6}{*}{$\begin{array}{l}\text { Creative teachers } \\
\text { provide many learning } \\
\text { strategies and are } \\
\text { consistent }\end{array}$} & \multirow{2}{*}{$\begin{array}{l}\text { Teacher used learning } \\
\text { strategies by using } \\
\text { video and journal }\end{array}$} & 4 & $\begin{array}{l}\text { The learning media used by your (compulsory) math } \\
\text { teacher while you are studying from home? }\end{array}$ \\
\hline & & 13 & $\begin{array}{l}\text { What do you think is the difference between teaching } \\
\text { compulsory math teachers in the first class and teaching } \\
\text { online (home)? }\end{array}$ \\
\hline & $\begin{array}{l}\text { Prefer lessons outside } \\
\text { their majors }\end{array}$ & 6 & What lessons did you like studying from home? Why? \\
\hline & $\begin{array}{l}\text { Activities given by the } \\
\text { teacher }\end{array}$ & 7 & $\begin{array}{l}\text { What do you think is the most creative subject teacher } \\
\text { during online learning? Why did you choose that teacher? }\end{array}$ \\
\hline & $\begin{array}{l}\text { Feeling about their } \\
\text { scores }\end{array}$ & 8 & $\begin{array}{l}\text { Did you get good math scores while studying at home? } \\
\text { Can you write down how much you scored? }\end{array}$ \\
\hline & $\begin{array}{l}\text { Consistent teacher in } \\
\text { learning assignment }\end{array}$ & 9 & $\begin{array}{l}\text { How many compulsory math assignments did your teacher } \\
\text { give you while studying from home? }\end{array}$ \\
\hline $\begin{array}{l}\text { Feeling bored and } \\
\text { tired while }\end{array}$ & Hopes and felling & 15 & $\begin{array}{l}\text { Imagine if you were a minister of education, principal, or } \\
\text { teacher in your country; what would you do to keep your } \\
\text { students learning }\end{array}$ \\
\hline & & 16 & $\begin{array}{l}\text { Write down words/sentences that represent how you feel } \\
\text { while studying from home? }\end{array}$ \\
\hline $\begin{array}{l}\text { Family and } \\
\text { technological support }\end{array}$ & Family & 14 & $\begin{array}{l}\text { What do you suggest (for students, teachers, parents, and } \\
\text { school authorities) to make learning from home better in } \\
\text { the future? }\end{array}$ \\
\hline & Internet & 5 & What obstacles did you face while studying from home? \\
\hline
\end{tabular}

(a) Theme 1. Prefer to study in a real classroom

From the interview, the students gave some experiences while they were studying online in their home about "need interaction with their classmates and teacher, learning resources, barrier in online learning, benefit from learning from home (online), and barrier when studying from home" were found in their experiences. In short, all students reported their experiences that they need interaction between themselves, teacher, and friends if they have some barriers while studying from home online to ask their teacher about the solutions right away. They also used the same typical applications that can help them as learning resources. But they thought that there is also benefit study from home.

"Mostly, the participants want to study in the real classroom. Some of the students gave comments, namely:

I like studying in class because interaction with friends and teachers makes me eager to learn and socialize" (MFF).

"Yes, I like a study in the class because I can exchange opinions with friends and teachers, and I'm also better at learning when the teacher explains in class because if I don't know, I can ask right away" (RKB) 
"Yes, I like to study, because I prefer to learn face to face, and if studying in the classroom the teacher explains more than giving questions, and one more teacher will not be able to corrupt with time" (DPT)

Meanwhile, the other male student, FA, had a different comment about it, he stated that:

"I would rather study in class than from home if there is no pandemic like this, but seeing conditions like this, I prefer to study at home... Although most students now prefer to study at home maybe because when they play, they are more satisfied like playing games, why did I choose to study in class because I was the type of person who didn't like to play games" (FA)

MFF felt that students needed interaction with his teacher and classmates to learn and also learn to socialize; RKB expected that students could exchange opinions with friends and teachers and students better at learning when the teacher explains in class because a student can ask something right away, DPT thought that studied in the classroom the teacher explains more than giving questions, and one more teacher will not be able to corruption with time.

It appeared that most students enjoy learning in class, and they want to interact with teachers and classmates. Students would expect to directly ask their teachers if they encounter obstacles or learning difficulties in the classroom. And they will understand better when there is a teacher by their side. On the other hand, a student stated that he would prefer to study in class rather than from home if there is no pandemic like this, but he prefers to study at home because of the current condition.

\section{(b) Theme 2. Creative teachers provide many learning strategies and are consistent}

Almost all students asked who the creative teacher was while studying at home and answered that their biology teacher was creative. Teachers in their opinions about "teacher used learning strategies by using video and journal, prefer outside their majors, activities given by the teacher, feeling about their scores, consistent teacher in learning assessment. Some of the student quotations were:

"The creative teacher is the Biology teacher because the teacher gives a lot of material in the form of videos and articles, so we understand it more quickly. The teacher also assigns us to make a video explaining the material we learned" (MFF)

“The biology teacher is creative because even though we don't directly meet when studying, our biology teacher makes our learning boring. Our learning is like playing games, for example: making crossword puzzles about the reproductive system and crossword puzzles that we exchange with other friends, so we answer we have our friend" (RKB)

"I think Biology teacher. Because learning is more like adventure and what I like when doing crosswords" (DC)

"The most creative teacher during online learning is the biology teacher, and he is my homeroom teacher. Why did I choose that mother? Because of all the teachers, I saw that the mother was one of the most creative teachers giving material to their students. For example, the mother often gave material through video. In the video, we analyzed or explained it back in the text. The teacher tried to make how her students did not get bored while studying at home, and in my opinion watching the video, I was not bored or bored when I was at home" (FA)

However, a student explained the other comment:

"The creative teacher is the mandatory mathematics teacher because the teacher is consistent with time, both studying in school and at home" (DPT)

As described by MFF that biology teacher gives a lot of material in the form of videos and articles so that the students can understand it more easily, RKB mentioned that biology teacher makes their learning not bored and like playing games, DC thought that learning is more like an adventure in Biology. FA added that the biology teacher gave material through video in the video to analyze or explain it back in the text, and the teacher tried to make how her students did not get bored.

It can be seen that students like biology teachers because the teacher provides them with what they need while studying at home, be it learning materials, games that can make students feel bored and provide their challenges for students who like challenges. Then the students asked about what lessons did you like studying from home 
and the reason also. While the other students still want classes that are in accordance with their major (Natural Science), they said:

"I like Math (mandatory) because the teacher gives material, new examples of questions, unlike some teachers who give questions directly without giving material" (DPT)

“I am one of those people who don't like or don't focus too much on one lesson. Why? Because I want to understand every material given by my teacher, including every material and every lesson. But because I am the type who likes to write, I prefer subjects that I write a lot, such as biology, Indonesian, compulsory mathematics" (FA)

Even though these public senior high school students have science majors, they prefer subjects outside their majors. Then they were asked what lesson they liked the most while studying at home. MFF argues that because he can find English learning resources, RKB also chooses lessons outside his major, Bahasa (Indonesian), because he likes stories and dramas. DC also chose crafts as his favorite lesson while studying at home; he loved art, whatever it is. Why some students like lessons outside of their major? The reasons are for those who have an interest in other subjects

(c) Theme 3. Feeling bored and tired while studying online.

Next, the student asked to reveal or give sentences representing how you feel while studying from home. Some of their quotations were:

I am very tired of studying online $(\mathrm{R} K B)$

While I was learning from home, I felt bored, bored, always imagining that this pandemic would be over quickly so that we students could learn face to face (DPT)

Hopefully, the covid-19 pandemic is over, and we can move on as usual. Even though studying at home is fun at school, we can be more fun (DC)

I want to thank the teachers for patiently teaching subject matter from bome. I like learning from bome because I can think more creatively (MFF)

The other student said:

Hopefully, the Covid-19 pandemic is over, and we can move on as usual. Even though studying at home is fun at school, we can be more fun (DC)

"I am very tired of studying online" (RKB)

"While I was learning from home, I felt bored, bored, always imagining that this pandemic would be over quickly so that we students could learn face to face” (DPT)

"Hopefully, the covid-19 pandemic is over, and we can move on as usual. Even though studying at home is fun at school, we can be more fun" (DC)

"I want to thank the teachers for patiently teaching subject matter from home. I like learning from home because I can think more creatively" (MFF)

The other student said:

"Hopefully, the Covid-19 pandemic is over, and we can move on as usual. Even though studying at home is fun at school, we can be more fun" (DC)

Some participants thought that they were bored studying online. Last, they asked about an idea if they were ministers of education, principal, or teacher in their country to keep your students learning from home during this lockdown. The following were excerpts from some of their statements:

"I am very tired of studying online. If I were minister of education", 
"1) I will give a free internet quota to students who are always actively studying online."

“2) I respond more to students' questions or input.”

“3) Trying to get students to make or understand material using games or other exciting things" (RKB)

"While I was learning from home, I felt bored, bored, always imagining that this pandemic would be over quickly so that we students could learn face to face. If I become a minister, I will first obey my schedule to enter first, create a conducive learning space, and then give the material. I will ask what is not understandable from the material. If everyone understands, then I will provide the task in stages" (DPT).

"Bored is one word that represents my feelings while studying at home. Not only am I every friend that I ask, they always say bored. Some things make them bored like me because I am the type of person who does not like to study at home, so I feel bored studying at home because I can't meet with friends can't joke and play with friends. When I became the minister of education, the most important thing or the thing I had to do was pay attention to each student whether they had facilities that had to be prepared and used. Moreover, not all students are not all parents of students can provide facilities, and what I do is so that students continue to study at home like making it easier for them to do assignments or collect questions, and talk to the school also to help and facilitate or provide facilities enough so that students can continue to do their work at home" (FA)

They provided a simple solution, and they talked about "hopes and felling". RKB thought that it is very tired of studying online. DPT mentioned that learning from home, felt bored, bored, and expected that this pandemic would be over quickly to learn face to face and FA thought that it felt bored studying at home because he can't meet with friends can't joke and play with friends. But, the other students have a different opinion about that.

It can be seen that the students felt bored studying at home, and they hope that the Covid-19 pandemic will end soon so that they can return to studying at school. But some students also stated that they like studying at home and studying at home is also fun, but it is more fun learning at school, and a student wants to thank the teacher who has been patient teaching them from home.

\section{(d) Theme 4. Family and technological support.}

Then the student asked about their suggestion (for students, teachers, parents, and school authorities) to make learning from home better in the future. All of the students suggested their parents. They talked about "family and internet. Some of the student quotations were:

"Hopefully, in the future, students are still enthusiastic about doing the assignments and don't complain easily. For teachers, I hope in the future teachers do not to time corruption again. We need guidance from parents, so we hope that parents can support or guide us in carrying out learning from home in the future. For the school, I hope that the school will provide a quota because the economics of all students are not the same". (DPT)

"My suggestion to the students is that the students be more supportive in the sense that they are always ready when online. My suggestion for parents is to understand better the condition of what their children behave and what they look like. And last my suggestions for schools, the school must have more creative activities, so students who follow online learning don't get bored". (DC)

"Teachers try to understand how students learn and respond more to students and try to make learning as interesting as possible, making materials into games, for example. For parents, to give more time to learn to their children and understand what children need. For schools, it's a good idea to deliver prizes to students who are diligent in studying online such as the internet quota, because some of the students are lazy to study online because they do not have a quota because they do not have money to buy a quota. With the school making something like that can trigger students to study harder". (RKB)

"My advice to students is that each student prepares things that must be done or prepared while studying at home. Take as much time as possible to be more consistent in learning at home. My suggestion to the teacher is to be more intelligent or more creative in giving questions, so students do not get too bored working on the questions given. My advice for parents is to give their children plenty of free time to study at home. It does not mean that they leave their homework, but seeing this condition, the school does require students to study at home. Every parent must understand what is done by their child" (FA) 
Some of the student obstacles while studying from home, they mentioned:

"My obstacles while studying from home are Networks and other interests such as helping parents" (DPT)

"The obstacles that I face while studying from home 1) Network that does not support, 2) lack of focus on learning because they are often asked to do homework" (RKB)

"Parents who don't trust their children. Because they think their children are addicted to using a gadget. And student need internet quota" (DC)

"Until now, the obstacle that I experienced was not there in the sense that most shared by my friends, such as networks, quotas even those who do not have Android" (FA)

DPT expected that guidance from parents as well, in the future parents can support or guide them in carrying out learning from home, and also expressed by DC that parents better understand the condition of what their children are and what they look like, on the same opinion RKB thought that parents could give more time to learn to their children and tried to understand what children need, FA expected that Every parent must understand what is done by their kids.

Parents must understand, support, and guide their children while learning from home. In this research, students prefer to study in a real classroom. It is in line with Hanh (2005) investigating students' and teachers' preferences for 32 classroom activities and found that students preferred more traditional methods such as studentcentered classroom activities [5]. Junior et al. (2019) stated that students faced three barriers during online learning: technological barriers, individual barriers, and pedagogical barriers [6]. There were personal barriers such as lack of family and organizational support (Park and Choi, 2009) [7]. The limitation of this research was that signal is not good to affect the mood during the interview and not ask follow-up answers to dig deeper information from participants.

\section{CONCLUSIONS}

Data revealed that the experience of students in using online learning platform during the COVID-19 lockdown in Indonesia could categorize into five themes, including (a) Prefer to study in a real classroom, (b) Creative teachers provide many learning strategies and are consistent, (c) Feeling bored and tired while studying online, (d) Family and technological support. The experience of natural science senior high school students in using an online learning platform during the COVID-19 lockdown in Indonesia can be categorized into four themes, namely (a) Prefer to study in a real classroom, (b) Creative teachers provide many learning strategies and are consistent, (c) Feeling bored and tired while studying online, (d) Family and technological support. The final suggestion for future studies is to provide the interview from the teachers and add more participants with different backgrounds so we can see the more profound insight into the study besides the students' interview.

\section{ACKNOWLEDGMENTS}

There is no funding for this research.

\section{REFERENCES}

[1] Minister of Education and Culture of the Republic of Indonesia. (2020). Circular number 4 of 2020 concerning the implementation of educational policies in the emergency spreading of corona virus disease (COVID-19). Dated March 24, 2020.

[2] Gilbert, J., Morton, S., \& Rowley, J. (2007). e-Learning: The student experience. British Journal of Educational Technology, 38(4), 560-573. https://doi:10.1111/j.1467-8535.2007.00723.x

[3] Symeonides, R., \& Childs, C. (2015). The personal experience of online learning: An interpretative phenomenological analysis. Computers in Human Behavior, 51, 539-

545. https://doi:10.1016/j.chb.2015.05.015. 
[4] Guba, E. G., \& Lincoln, Y. S. (1994). Competing paradigms in qualitative research. In N. K. Denzin \& Y. S. Lincoln (Eds.), Handbook of qualitative research (pp. 105-117). Thousand Oaks, CA: Sage.

[5] Hanh, P. T. (2005). Learners' and teachers' preferences for classroom activities. Essex

[6] Junior, F. A. C., Botelho, E. D. A., Rego, M. C. B., Faiad, C., \& Ramos, W. M. (2019). Attitudes towards online learning: what do Brazilian students think about?. Turkish Online Journal of Distance Education, 20(4), 117-134.

[7] Park, J.-H., \& Choi, H. J. (2009). Factors influencing adult learners' decision to drop out or persist in online learning. Educational Technology \& Society, 12(4), 207-217. 